The Reintroduction of the Social Security Statement and its Effect on Social Security Expectations, Retirement Savings, and Labor Supply across the Age Distribution

\author{
Philip Armour
}

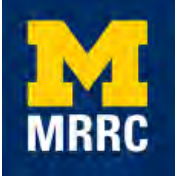

Project \#: R-UM17-05 


\title{
The Reintroduction of the Social Security Statement and its Effect on Social Security Expectations, Retirement Savings, and Labor Supply across the Age Distribution
}

\author{
Philip Armour \\ RAND Corporation \\ September 2017 \\ Michigan Retirement Research Center
University of Michigan
P.O. Box 1248
Ann Arbor, MI 48104
www.mrrc.isr.umich.edu
}

(734) 615-0422

\section{Acknowledgements}

The research reported herein was performed pursuant to a grant from the U.S. Social Security Administration (SSA) funded as part of the Retirement Research Consortium through the University of Michigan Retirement Research Center Award RRC08098401-09. The opinions and conclusions expressed are solely those of the author(s) and do not represent the opinions or policy of SSA or any agency of the federal government. Neither the United States government nor any agency thereof, nor any of their employees, makes any warranty, express or implied, or assumes any legal liability or responsibility for the accuracy, completeness, or usefulness of the contents of this report. Reference herein to any specific commercial product, process or service by trade name, trademark, manufacturer, or otherwise does not necessarily constitute or imply endorsement, recommendation or favoring by the United States government or any agency thereof.

Regents of the University of Michigan

Michael J. Behm, Grand Blanc; Mark J. Bernstein, Ann Arbor; Shauna Ryder Diggs, Grosse Pointe; Denise Ilitch, Bingham Farms; Andrea Fischer Newman, Ann Arbor; Andrew C. Richner, Grosse Pointe Park; Ron Weiser, Ann Arbor; Katherine E. White, Ann Arbor; Mark S. Schlissel, ex officio 


\title{
The Reintroduction of the Social Security Statement and its Effect on Social Security Expectations, Retirement Savings, and Labor Supply across the Age Distribution
}

\begin{abstract}
This paper examines how the 2014 reintroduction of the Social Security statement, staggered by every fifth birth year, affected American Life Panel respondents' Social Security expectations, savings behavior, and labor supply. The rich panel design of the ALP allows for controls for prior Social Security knowledge and behavior, and a specialized module fielded to ALP respondents elicited recall of the Statement and use of alternate information. The majority of individuals who were sent a Statement recall receiving one, with high rates of nonrecall concentrated among younger respondents. Statement recipients and my Social Security account holders highly value the information therein for retirement planning. Recipients measurably increased their likelihood of expecting future benefits, especially disability benefits, and were less pessimistic about future cuts to the program. Recipients were more likely to work after receipt, especially younger workers, although those already working more than 40 hours per week decreased their hours worked on the intensive margin. There were no statistically significant effects on retirement savings, although additional research is required for estimating heterogeneous effects.
\end{abstract}

\section{Citation}

Armour, Philip. 2017. "The Reintroduction of the Social Security Statement and its Effect on Social Security Expectations, Retirement Savings, and Labor Supply across the Age Distribution.” Ann Arbor, MI: University of Michigan Retirement Research Center (MRRC) Working Paper, WP 2017-373. http://mrrc.isr.umich.edu/wp373/ 


\section{Introduction}

The Social Security Administration provides programs amounting to a quarter of the federal budget, greatly alleviating poverty among the elderly and disabled; however, the extent to which individuals understand the incentives contained in these programs and change their behavior in response is still unclear despite the necessity of measuring these behavioral responses in welfare analyses. Although the cost of these programs is clear and often a source of political debate, individuals' knowledge of program structure and benefit entitlements are low (Greenwald et al. 2010). However, for the past two decades, SSA has embarked on a proactive information-dissemination campaign to better educate all potential beneficiaries concerning their suite of SSA benefits. This campaign has led to greater program knowledge among potential beneficiaries as measured variously by the ability to provide an estimate of future Social Security (SS) benefits, the accuracy of this estimate, knowledge of specific program details, and take-up of SS programs (Biggs 2010; Mastrobuoni 2011; Smith and Couch 2014; Liebman and Luttmer 2015; Smith and Couch 2016; Armour forthcoming), but these outcomes are often specific to certain subgroups or limited to existing questions from surveys administered more than 20 years ago, when the largest SS information dissemination campaign - the Social Security statement was phased-in.

This paper instead focuses on the reintroduction of the statement in 2014 and provides an analysis of its impact on a range of SS knowledge and expectations, both generally and specific to the individual, by exploiting the unique opportunity to field a survey to American Life Panel (ALP) respondents who previously answered a survey module with detailed questions on Social Security knowledge. Most innovatively, this research examines not just shifts in expectations but also savings and work responses for the entire adult American age distribution, not just those 
nearing retirement. Furthermore, it provides estimates based on the current information environment, including the mediating effects of having an online my Social Security account.

By comparing the expectations of approximately 1,200 respondents in the nationally representative ALP and exploiting the reintroduction of the statement - discontinued in 2011 but reintroduced in late 2014 such that individuals receive a statement every fifth birthday (e.g., 25, 30, 35, 40) - I compare SS expectations, savings, and labor supply among the same respondents from prior surveys fielded in 2010, 2013, and early 2014. I ask these respondents additional questions as to dynamics of the SS program, whether they have a my Social Security account, and the ways in which they use these information sources.

The central findings include that individuals highly value information about their benefits from SSA. Individuals report the statement and my Social Security accounts useful for planning for retirement and deciding when to claim Social Security benefits, especially nearing retirement. Additionally, after being sent a statement, individuals are more likely to report expecting to receive future benefits, especially disability benefits. They are also less pessimistic about the possibility of future cuts to the program: There is a more than 5 percentage point drop in their reported likelihood that Congress will make the SS system less generous in the next 10 years.

However, among those already expecting benefits, there does not appear to be much change in claiming expectations, either the age of claiming or the amount upon claiming. There are also no statistically significant changes in retirement savings through IRAs, pensions, or other long-term savings vehicles, although these estimates are preliminary and future analyses by subgroups may provide sharper inferences.

Perhaps not surprisingly given the previous research on the effect of the statement (Armour and Lovenheim 2017), there are heterogeneous effects of information provision and 
information seeking. For example, my Social Security account holders tend to be better informed about SS program details, even before signing up for their accounts. Additionally, among those sent statements, many either did not receive them or forgot having received them; these individuals are highly skewed toward the younger end of the age distribution.

Finally, consistent with prior research, there are labor supply effects that are highly heterogeneous. Although those previously at the very top of the labor supply distribution appear to have somewhat reduced their hours worked after having been sent a statement, statement receipt is also associated with re-entry into the labor force among those previously not working.

Overall, these results point to a strong role of SS communications in shaping expectations over the future of these benefits and a tight linkage between SS retirement claiming and labor supply informed by this information. Individuals also highly value this information, whether in the form of the Social Security statement or online my Social Security accounts.

The rest of this paper is organized as follows: Section 2 discusses the history of the statement, the relevant literature, and the variation in its reintroduction; Section 3 describes the data used in these analyses; Section 4 describes the methodology and results; and Section 5 discusses and concludes.

\section{The Social Security Statement}

Starting in 1990, the Social Security Administration began providing standardized benefit statements for all individuals who requested them, and starting in late 1994, statements were automatically sent out. These Social Security statements eventually were sent annually to all individuals 25 and older between 2000 and 2011 who were not receiving SS benefits under Title II, and who had a retrievable mailing address from tax filings. They contained personalized information about OASDI benefits upon retirement, disability, or death. Although the statement 
stopped being mailed out after March 2011 for budgetary purposes, it was reintroduced in September 2014 after the Joint Explanatory Statement to the Consolidated Appropriations Act of 2014 that directed SSA to develop a plan that would "include a significant restoration of the mailing of statements to ensure that individuals are informed of their contributions and benefits under Social Security programs and have an opportunity to review their earnings records and correct any errors in a timely manner." ${ }^{11}$ Instead of implementing the previous dissemination strategy of sending all potential beneficiaries a statement every year, SSA opted to send a statement to individuals three months before every birthday ending in a 5 or 0 . Hence, an individual turning 55 in December of 2014 was sent a statement in September of 2014, whereas an individual turning 55 in November of 2014 would not be sent a statement until August of 2019. These differences in the timing of receipt due to one's birth year relative to the statement's reintroduction are the crux of my identification strategy of the statement's effect on my outcomes of interest.

However, returning to our knowledge as to the statement’s first introduction: Consistent with the scale of the mailings, the accuracy of recent addresses reported on tax forms, and the salience of receiving a document from the Social Security Administration with personalized benefit information, prior research has found high rates of recall of statement receipt in the 1990s. Greenwald et al. (2010) found that more than two-thirds of individuals sent statements recall having received one. ${ }^{2}$ Of those recalling receipt, 83 percent-90 percent report having read it carefully, with more than 90 percent remembering that it contained personalized benefit calculations. A series of GAO reports finds results consistent with Greenwald et al. (2010).

\footnotetext{
${ }^{1}$ Congressional Record Vol 160., No. 9 (https://www.gpo.gov/fdsys/pkg/CREC-2014-01-15/html/CREC-2014-0115-pt2-PgH475-2.htm)

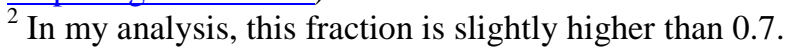


Smith and Couch (2014) show that personalized knowledge of the Full Retirement Age, own monthly benefit, and individual Social Security incentives is lacking before statement receipt. This is despite there being rather high general knowledge about the Social Security program among Americans approaching retirement.

Because of the structure of the statement's initial introduction — before all potential beneficiaries older than 25 were sent a statement starting in Fiscal Year (FY) 2000, those 60 and older were sent a statement in FY 1995, those 58 to 60 in FY 1996; in FY 1997, 53 to 58; in FY 1998, 47 to 53; and in FY 1999, 40 to 47 — researchers have been able to isolate the statement's effect from age-specific differences and time trends. These researchers have found that receipt of the statement improves these areas of Social Security knowledge, as evidenced by Mastrobuoni's (2011) findings of fewer errors in HRS recipients' estimated future benefits compared to projected benefits after they receive a statement. Armour (forthcoming) found that SSDI application rates increased after statement receipt, driven by individuals at least as likely to be accepted onto the program as the average applicant. These results indicate that the statement was a highly effective outreach effort in terms of being read by the targeted recipients, with strong recall, both qualitatively and quantitatively, of the information presented therein. That Americans lack detailed knowledge about their own Social Security benefits and the incentives they face highlights the importance of providing personalized Social Security information to them, which is what the statement did. However, these earlier studies suffered from the same drawbacks: They were limited to existing surveys with only a small range of questions on SS knowledge and expectations. Resulting inference of the mechanisms of the statement's impact on the outcomes measured was thus rendered infeasible. Although administrative data-based analyses can provide population-wide or certain subgroup estimates, these previous studies indicate substantial 
heterogeneity by characteristics generally not found in administrative data (e.g., health status, prior SS expectations).

As briefly discussed above, the statement's was reintroduced starting in September 2014. A statement was sent to every individual not currently collecting SS benefits under Title II and who had filed payroll taxes with a retrievable address. Although unreported in this analysis for the sake of brevity, once one controls for age and year, no other characteristics predict being sent a statement after 2014 in any given year. This analysis thus uses variation in which age individuals are turning, and the resulting variation in having been sent a statement, to identify the intention-to-treat impact of the statement on expectations, savings, and labor supply separate from observable and unobservable confounding characteristics.

The statement itself contains information on projected retirement benefit levels if a retiree elects to receive benefits at the Early Eligibility Age (62), the Full Retirement Age (between 65 and 67, depending on birth cohort), and age 70. Furthermore, information on one’s family survivor benefits are included, as well as one’s current disability insurance coverage status. To construct the benefit information, SSA uses each individual's earnings history up to the calendar year before the statement's release. The SSA also includes expected future earnings up to the three ages listed on the statement, assuming constant earnings and no inflation (or, equivalently, national average wage growth equivalent to average price growth).

Although the statement should only increase knowledge of the existence of programs, its effect on expected benefits will be heterogeneous based on prior expectations. Similarly, the effect of statement receipt on savings and labor supply is ambiguous, depending on whether the statement provides a benefit estimate higher or lower than that expected. Essentially, the statement provides individuals with projected information about their monthly retirement 
benefits and current information on potential disability benefits. Prior work has shown that there is a sizable Social Security wealth effect on labor supply (Friedberg 2000; Liebman, Luttmer, and Sief 2009) and that the statement led workers to more accurately predict their projected benefits (Mastrobuoni 2011). We would expect, therefore, highly heterogeneous responses depending on prior expectations. In this paper, I test the degree to which expectations change, as well as savings rates and labor supply, leaving future analyses to explore how the statement's information may deviate from prior expectations using additional ALP modules.

\section{Data}

To this end, I field a new survey in the American Life Panel (ALP) to study how expectations over own SSA benefits shift after statement receipt, as well as how retirement savings and labor supply change as a result. The ALP is a nationally representative internet panel survey, initially begun in 2006. There currently are more than 6,000 active participants. The greatest advantage of the ALP is that one can link responses across all survey modules a

respondent has answered, as well as target a module sample based on those who filled out specific prior modules. I took advantage of this ability by focusing on the more than 2,000 respondents still active in the ALP who answered an extensive module on SSA knowledge in 2010, providing a baseline level of detailed SSA program knowledge for each respondent. Furthermore, most of these same respondents completed the full set of nonexperimental 2012 Health and Retirement Study (HRS) modules in 2013 or early 2014. These modules include information on own expected SSA benefits, as well as contributions to retirement savings and labor supply, again providing pre-statement measures of these outcomes. 
The full content of the ALP module fielded for this study - Module Survey 479 (ms479) - is available upon request. ${ }^{3}$ There are six broad categories of information elicited from respondents of the prior Social Security knowledge survey and HRS modules: receipt and expectation of SS benefits, how these benefits change with different work and claim ages, current and expected labor supply, current retirement savings holdings and activity, recall and use of my Social Security accounts and Social Security statements, and general impressions of communications from and about SS benefits. The analysis in this paper focuses on the effects of the statement on current expectations, savings, and labor supply; however, the possibility of linking to additional ALP modules that elicited individuals’ work histories will allow for future heterogeneous analyses by deviation from expectations.

In contrast to prior economic analyses of the statement’s impact, I ask respondents whether they remember receiving a statement, although past audit studies have found more than 66 percent remember receiving a statement (Smith and Couch, 2014). More specifically, the outcome measures for this analysis are from the 2012 HRS modules fielded to ALP respondents in 2013: Do you expect to receive SSA benefits, at what age, and what do you expect them to be; how many hours do you usually work per week, how many weeks do you usually work per year; did you actively contribute to any Type B/Type A+B (DC and hybrid DC/DB) plans; and did you actively contribute to an IRA?

Using these standardized HRS question outcomes allows for both strong internal comparisons across ALP modules, as well as external comparisons to past findings using the HRS itself. Additionally, the survey asks questions about access to SSA knowledge more generally: e.g., have you registered for an online my Social Security account that allows you to

\footnotetext{
${ }^{3}$ Contact parmour@rand.org for the paper version of the survey.
} 
observe your earnings history and projected benefit? Have you accessed this account in the past year? Have you received a Social Security statement in the mail in the past year?

Finally, respondents are then asked for open ended comments. Although few respondents provide these comments, they provide qualitative evidence of the strength of some reactions. For example, these selected responses indicate how some individuals interact with the information provided by SSA:

"After SSA stopped sending the yearly statement I signed up online so I could view the information and create a PDF to save.”

"I'm a widow so I began receiving benefits at the age of 60 . This year someone reapplied for my benefits, not me, I received a letter from ss because my regular benefits were much lower than survivor benefits so that had to be addressed. I went to the local office to get this cleared up.”

"I didn't ever use the site or telephone info or stop by the local office until I was already on the verge of retirement, so the info I got was more in line with finding out what my status was, not for use in planning future activities.”

\section{Methodology and Results}

The specific research design is driven by the statement's reintroduction: From FY 2000 to 2011, statements were automatically mailed to individuals with an address available from the IRS. These statements were sent out three full calendar months prior to recipients' birth month for every payroll tax payee on file every year, but due to budgetary reasons, SSA ceased automatic mailings in March 2011. However, these statements represent a legal mandate, and SSA resumed their mailing in September 2014, with two important changes: First, individuals with my Social Security accounts would receive reminder emails once a year in lieu of paper statements; and second, individuals without my Social Security accounts would receive a paper statement three months before every fifth birthday (e.g., 25, 30, 35, etc.). The crux of my 
research design is correspondingly twofold: The ALP survey elicited from individuals as to whether they report having a my Social Security account before they would have been sent a statement ("Had my Social Security Account before Recent statement” or simply “Had my Social Security Account”), and respondents are grouped according to whether they have received a statement since its reintroduction ("Recent Statement"). The identifying variation in information provision is illustrated by the following thought experiment: Compare two individuals, one who just turned 30 in late 2014, and hence will receive a statement for the first time in almost four years, and another who just turned 31 in late 2014, and hence won't receive a statement for another four years. These individuals have otherwise very similar demographics (observable and controllable) and face similar economic environments, thereby differing with regard only to how recently they've received a Social Security statement. This example applies more generally: I compare not just 30 versus 31 year olds, but the approximately 60 percent of those who have received a recent Statement between September 2014 and September 2017 and the 40 percent who have not, across the age distribution. Additionally, due to ALP participation, I observe prestatement SSA knowledge (see Greenwald et al., 2010 for a description of the full range of information about SSA elicited from ALP respondents in the corresponding module), both generally and specific to individuals' own expected SSA benefits, as well as retirement savings and labor supply. I then control for any time-invariant differences across these birth-cohorts, cohort-wide time shocks, baseline Social Security knowledge, and having a my Social Security account, and then isolate the separate effect of statement receipt on expectations and behavior. In general, I estimate the following intention-to-treat linear equation; 


$$
\begin{gathered}
\text { Outcome }_{i, 2017}= \\
\alpha+\Gamma X_{i, 2013}+\beta * \text { RecentStatement }_{i, 2017}+\Lambda * \text { PriorKnowledge }_{i, 2010}+ \\
\gamma \text { PriorMySSA }_{i, 2017}+\varepsilon_{i, 2017} \text { (1) }
\end{gathered}
$$

with standard errors clustered at the age-specific level. The covariates in $X$ include age, age squared (or age group, where indicated), race/ethnicity, sex, and education. These covariates may also include pre-September 2014 measurements of the outcome variable of interest. "Prior Knowledge” refers to each of seven questions that separately enter the regression with independent effects. "Recent Statement” indicates whether the respondent would have been sent a statement since September 2014. "Prior mySSA" refers to having a my Social Security account before being sent a recent statement, as reported by the respondent, and thus receives a distinct information intervention (an annual email reminder to check his/her account). Although the analyses included in this paper limit to ITT estimation, future analyses may include first stage estimates of the impact of the statement on expectations and the subsequent impact of changes in expectations on outcomes of interest by drawing upon additional ALP modules eliciting complete work histories.

\section{Descriptive Statistics}

Before beginning this analysis, Tables 1 through 6 present descriptive statistics of demographics, prior SS knowledge, SS expectations, SS expected benefit type, long-term savings, and labor supply. These statistics are presented not just by the 2017 measurement in the current ALP module - ms479 - but also by 2013 and early 2014 measurements from ALP respondents' completion of the corresponding Health and Retirement Study (HRS) modules. ${ }^{4}$

\footnotetext{
${ }^{4}$ The exact timing of finishing this 2013 survey varied, but all respondents in this analysis completed it before any would have received a reintroduced Statement.
} 
Also, the 2017 statistics are broken down by whether an individual reports having signed up for a my Social Security account and whether an individual has or has not been sent a recent statement. All statistics presented, with the exception of sample sizes, are weighted with analytic weights to be nationalLY representative of the adult U.S. population.

Table 1 presents demographics by access to Social Security information, namely, currently having a my Social Security account, and whether the respondent had recently been sent a statement (i.e., sent a statement since its reintroduction in 2014). Although some of the demographic characteristics appear different across being sent a statement, specifically race, these differences are not statistically significant when multiple hypothesis testing corrections are applied.

More notably, the population that has elected to sign up for a my Social Security account is disproportionately older, indicating that although technological engagement is higher among younger cohorts, this generational effect is more than overcome by the importance of SS benefits for older cohorts. Online my Social Security account holders also are disproportionately male, as well as more likely to be other than white or black. Although they are more likely to be more highly educated, they have a lower average income, thus they may be more dependent on SS benefits, and hence more motivated to fully understand these benefits going forward. Many of these characteristics are observable via administrative SS data and can be cross-checked with analyses of my Social Security account data.

Table 2 presents the distribution of correct answers for Greenwald et al. 's (2010) sevenpoint metric of SS knowledge. All of these measures are from the 2010 ALP survey module "What Do People Know" and, therefore, occur at least four years before the reintroduction of the statement. At that time, respondents would have been receiving annual Social Security 
statements. As Greenwald et al. note, knowledge of SS benefit details is low on average. Fortunately for this analysis, there are no statistically significant differences across this knowledge for those sent a recent statement versus those who did not, either item-by-item or as an overall sum. However, for those who have reported having a my Social Security account (the vast majority of whom report having signed up for such an account in the past five years), knowledge of program details is systematically and statistically significantly higher. There is thus a substantial amount of selection into signing up for my Social Security accounts, since they are more knowledgeable about SS benefit details before even having a my Social Security account.

Table 3 provides statistics as to current SS benefit receipt, expectations of future SS benefit receipt among current nonbeneficiaries, and perceived likelihood of Congressional action reducing the generosity of SS benefits, either overall or with respect to the respondent's own benefit, in the next 10 years. This Table provides these statistics from the 2013 and early 2014 ALP modules in which respondents answered all nonexperimental HRS modules, as well as from the current ms479 ALP survey module. It further splits the latter measurements by holding a my Social Security account and having recently been sent a statement.

Although there are slightly more SS recipients in the 2017 measures, otherwise, there are not many notable differences, with the exception of respondents in 2017 being more optimistic as to the likelihood of Congress making SS less generous (i.e., they considered it less likely for Congress to make SS less generous). It is also worth noting that those with my Social Security accounts are much more likely to be SS beneficiaries. These my Social Security account holders are also much less likely to expect Congress to make SS less generous in the near future. 
Among those who were recently sent a statement versus those who were not, there is a small but statistically significant increase in the fraction that expects future SS benefits. Similarly, there is a small decrease in the perceived likelihood that Congress will make SS less generous overall. Otherwise, there are no clear differences.

Table 4 presents results over which types of benefits the weighted 53 percent of respondents in 2017 expected to receive in the future. Individuals were free to select multiple types of benefits, hence they can sum to greater than one. Of those expecting benefits, the vast majority anticipate receiving SS retirement benefits. However, 9 percent expect to receive disability benefits, and another 9 percent expect to receive spousal benefits, with much smaller fractions expecting to receive survivors or dependent benefits, or unsure of which benefits they may receive. Given that the fraction of individuals who will receive survivors' benefits is substantially higher than 2 percent, there is clearly a lack of knowledge as to this benefit eligibility, the likelihood of eventual receipt, or whether these benefits are distinct from retirement benefits.

Although there are no statistically significant or substantial bivariate differences in which type of benefits individuals expect to receive based on having been sent a statement recently, those who have a my Social Security account display markedly different expectations. Namely, they are nearly twice as likely to expect to receive disability benefits, more likely to expect retirement benefits, and less likely to be unsure of which benefit type they will receive.

Table 5 shows savings behavior among respondents. I note here that the structure of eliciting information about saving in ALP survey module 479 is substantially different from that in the prior ALP modules in which respondents completed the HRS survey questions. As such, direct comparisons across these savings methods are difficult and require deeper analyses. As a 
result, I will only briefly discuss these comparisons, which can be broken down into three savings vehicles — Individual Retirement Accounts (IRAs), DC Pensions (Pension), and other long-term savings — and three metrics - whether there is such a vehicle in the household, whether someone actively contributed to it, and how much was contributed. Among those who were recently sent a statement, these measures are slightly higher, perhaps suggesting a higher rate of savings. For those with my Social Security accounts, contribution rates and possession of these savings vehicles are both higher, again suggesting a strong correlation between those who actively seek out SS information via these accounts and those who are preparing to save.

Table 6 focuses on more easily comparable measures across prior ALP modules and the current survey module 479: work status and hours work. As is initially clear, there are actually fewer individuals reporting non-zero hours worked in the 2017 survey than the 2013/2014 ALP survey. However, among those working, the average hours worked is higher, since more workers are working at least 40 hours per week.

Consistent with my Social Security account holders being more likely to be current SS beneficiaries, they are also less likely to be currently working. However, those who have recently been sent a statement are more likely to be employed than both my Social Security account holders and those who have not recently been sent a statement. Further, conditional on employment, they work more hours on average.

All of these descriptive statistics suggest that those with my Social Security accounts are systematically distinct from the general population: They are more likely to be receiving SS benefits, less likely to be working, more knowledgeable about SS, more confident in its future, more likely to expect to receive disability benefits, more educated, and more frequent savers. To that end, in multivariate regression below, I will control for those who report signing up for a my 
Social Security account before they would have been sent a recent statement in order to account for these differences and the different information environment (annual email reminder versus paper document), as well as to avoid conflating any effect of receiving a recent statement on signing up for a my Social Security account.

Further, there are some apparent differences across those recently sent a statement more likely to expect future benefits, more confident in SS's continued generosity, more likely to be working — but they are not substantial and require controlling for covariates to infer the effect of the statement itself. However, before embarking on regression analyses, I first turn to what people report about their interaction with my Social Security accounts and statements.

\section{Memory of and Attitudes toward Social Security Information}

Tables 7 and 8, as well as Figure 1, review how well individuals recall receiving statements and what they found useful about them. Table 7 first presents the weighted fraction of survey module 479 respondents who report receiving SS income, and thus would not have been recently sent a statement. Among those not receiving SS income, who would have been sent a statement, more than 70 percent report ever having received a statement. A few of these individuals would not have been sent a statement ever - a few are young enough not to have received a statement before 2011 and have not been sent a recent statement, some may not have filed taxes to have retrievable addresses, and some may simply have moved without having their mail forwarded. However, this rate of recall of these intended-to-treat with statement receipt is even higher than prior estimates of approximately two-thirds.

The next row shows the fraction that would have been sent a statement since 2014 or those who have a my Social Security account and, thus, would be reminded to check their account. Slightly fewer than 60 percent of respondents had an informational reminder or 
statement sent to them, while slightly more than 40 percent have not. Nearly a quarter of individuals who are not receiving SS income report having a my Social Security account, ${ }^{5}$ with 14 percent percent of individuals who would have been sent a recent statement were not sent one due to holding such an account. Finally, of those who were sent a recent statement, nearly a third does not recall having received one. This lack of recall may be due to having forgot receiving one, having moved, or not having a retrievable address.

Figure 1 shows the distribution of those who did not remember receiving a statement but, due to their birth year, should have been sent one. As is clear, this distribution is starkly skewed toward the young, with a mode of approximately 30. Future research is required to disentangle the reasons for this lack of recall.

Table 8 presents means regarding how useful respondents found the Social Security statement and their my Social Security account (among those recalling receiving a statement or signing up for an online account). The majority of individuals found these information sources useful, although those who had a my Social Security account found it a more useful resource than statement recipients found the statement. However, the statement was found to be more useful for retirement purposes, both in deciding when to retire and when to claim SS retirement benefits. Although retirement planning accounts for the vast majority of perceived usefulness, individuals’ my Social Security accounts were reported to be more useful for nonretirement, and in particular, SS disability benefits.

\footnotetext{
${ }^{5}$ Given that there are approximately 30 million my Social Security accounts, this fraction seems high, although among the internet-connected respondents, adult individuals not currently receiving SS income, this fraction may not be as much as an overestimate as initially appears. The question in ALP module 479 was intended to be particularly discriminating and not include individuals who just visited the SSA website; they were asked "Have you ever signed up for an online my Social Security account from the Social Security website? This account provides personalized benefit information and allows you to check your history of earnings. You would have had to provide your name and Social Security Number to create a user ID and password.”
} 
With these results in hand - that individuals generally report high levels of statement receipt, of take-up of my Social Security accounts, and of the usefulness of these informational resources - we next turn to regression estimates of the impact of the statement's reintroduction on expectations, savings, and labor supply.

\section{Causal Impact of the Statement's Reintroduction on Expectations, Savings, and Work}

Tables 9, 10, 11, and 12 test the effect of being sent a statement since its 2014 reintroduction on expectations of one's own SS benefits, expectations about program dynamics and generosity in general, savings behavior, and labor supply, by estimating variations of equation 1.

Table 9 first presents results of the impact of being sent a statement since 2014 on one’s own expectations of future SS benefits. Although bivariate comparisons indicated that statement receipt may be associated with a greater likelihood of expecting future benefits, column 1 indicates that this impact is actually quite large and statistically significant: There is a 12 percentage point increase in the likelihood of expecting future SS benefits. Since the mean of this outcome is approximately 50 percent, this effect is substantial, showing that recent statement receipt, even after having been sent statements annually until 2011, leads to greater expectation of future benefits.

Next, there appears to be little aggregate impact on the expectation of disability benefits, although having a my Social Security account itself is correlated with expecting a higher benefit. However, when limiting the sample to those who previously did not expect any SS benefits in their 2013/2014 ALP survey, there is a substantial increase in the likelihood of expecting SS 
disability benefits. ${ }^{6}$ Among those who previously expected SS benefits, recent statement receipt has a smaller, statistically marginal negative effect. Although not shown, 2010 knowledge of SS covering disability has a highly significant and negative correlation with expecting disability benefits among those previously not expecting SS benefits, suggesting that the Statement may have provided novel insight as to personalized coverage of SS disability benefits even among those who knew that there are SS benefits for those with long-term disabilities.

Although not shown, there are no statistically significant effects of recent Statement receipt on the expectation of receipt of other SS benefit types. Columns 5-8 of Table 9 indicate little average effect of the statement on expected claim age or expected monthly benefit, with or without controlling for previous expectations of these outcomes. However, there may be substantial nonmonotonic heterogeneity with regard to prior knowledge that further research may uncover. But the overall conclusion from Table 9 is that recent Statement receipt does increase expectation of receiving any SS benefit, as well as receiving SS disability benefits if the respondent previously did not expect to receive any SS benefits.

Table 10 reviews regression results as to the understanding and expectations over the program in general. The first four columns report outcomes corresponding to four scenarios in survey module 479: Given the benefit respondents provided, the respondent is asked whether this benefit would change if he or she 1) earned 25 percent more, 2) earned 25 percent less, 3) claimed at later age, and 4) claimed at an earlier age. However, there appears to be no statistically significant impact of having been sent a recent Statement on these outcomes, showing that the Statement does not have an easily detectable, direct impact on how individuals perceive the dynamic nature of SS benefits.

\footnotetext{
${ }^{6}$ Because being sent a recent statement is orthogonal to non-age observables, mean reversion should be captured by the other covariates in the model.
} 
Columns 5 through 8 report the impact of recent Statement receipt on respondents' perception of how likely Congress is to make SS benefits less generous, either overall (columns 5 and 6) or with regard to one's benefits (columns 7 and 8). The Statement systematically reduces this likelihood of Congress cutting the overall generosity of SS by between 5.3 and 7.3 percentage points, depending on whether one controls for respondents’ prior expectation. Given the mean of approximately 60 percent, this effect represents approximately a 10 percent reduction in this perceived likelihood, a substantial increase in optimism as to continued program generosity. However, there is no clear corresponding effect on respondents' perception of the impact on their own SS benefits. ${ }^{7}$

Tables 9 and 10 both show that recent Statement receipt has a direct impact on expectations over future SS benefits, both in levels and compositionally, a result that prior research has had difficult establishing. Tables 11 and 12 next explore the impact on savings and work behavior.

Table 11 shows the impact of recent Statement receipt on measures of retirement savings, the most likely channel for savings changes due to Social Security information provision. The current specification finds no statistically significant impact on savings; however, the confidence intervals on many of these estimates are too large to rule out correspondingly large behavioral impacts. As discussed during the review of Table 5, these savings measures do not have direct parallels across survey modules, and hence additional research is required to fully rule out or rule in any behavioral effects. Furthermore, and this caveat applies to both this table and the next, theory suggests substantial heterogeneity in response that the current analysis does not explore.

\footnotetext{
${ }^{7}$ It is worth noting that there are a substantial number of "irrational” responses to these questions, in which respondents report a higher likelihood of Congress cutting their own benefit than cutting the program at all, calling into question the validity of respondents' interpretation of this latter question as independent or conditional.
} 
Future research drawing upon those ALP modules that elicit additional savings information and work history, may be able to shed light upon corresponding behavioral savings responses.

Table 12 reports regression coefficients of the impact of being sent a recent Statement on work behavior. There appears to be a slight increase in the likelihood of working overall among recent Statement recipients, but this effect is not statistically significant. However, among those who were not working in 2013/2014, being sent a recent Statement resulted in a substantial increase in the likelihood of any work. ${ }^{8}$ Estimates of changes in hours work between 2013/2014 and 2017, as presented in Columns 4-8, show a range of impacts. First, there appears to be a small and insignificant effect. However, among those younger than 50, the Statement has a net positive effect in the number of hours worked. When decomposed by prior hours worked, those working more than 40 hours per week decrease their labor supply. ${ }^{9}$ This effect persists across all age groups and for those 50 to 59 and 60 and older. There are marginal increases in labor supply among those working 30 to 40 hours per week, as well as statistically insignificant but economically large increases at the bottom of the distribution, but these effects are not robust. These patterns are consistent with Armour and Lovenheim (2017), although distinct in magnitude (smaller) and without as large an increase at the bottom of the distribution.

However, as with the discussion of the null savings results, theory predicts substantial heterogeneity in response by the direction and magnitude of the Statement's “corrections" of SS benefit expectations. Full analysis of labor supply reactions to recent Statement receipt requires a full first stage measurement of this heterogeneity, requiring matching to additional ALP modules

\footnotetext{
${ }^{8}$ Once again, it is worth noting that mean reversion should be on average independent of hitting an age ending in a 5 or 0 in the specific years of the statement's reintroduction, and in the presence of no actual statement effect, this coefficient should be zero.

${ }^{9}$ Only subanalyses by prior-hours-worked category and age group are shown for those 50 to59 or older than 60 , since sample sizes for those younger than 50 are too small for this fine an analysis: All coefficient have very large standard errors with no statistically significant coefficients.
} 
recording respondents' work histories, an exercise for future research. Regardless, being sent a recent statement appears to have a measurable impact on the labor supply of specific subgroups.

\section{Discussion, Future Research, and Conclusion}

The descriptive statistics, recall, usefulness, and regression results all point to the Statement's reintroduction having a measurable impact on individuals' expectations for future SS benefit receipt (increasing expectations of future receipt, especially for SS disability benefits, and shoring up confidence in continued program generosity), may encourage work among younger workers or those previously not working (while perhaps slightly discouraging work among those previously working more than 40 hours per week), and individuals find the information therein, as well as in the my Social Security account, highly useful for retirement planning.

However, this analysis is the first step in using American Life Panel data in analyzing the impact of the Statement's 2014 reintroduction on individuals' expectations, savings, and labor supply. Future analyses can take advantage of additional survey modules eliciting full earnings histories from respondents. Including these measures would finally allow Statement research to move past intention-to-treat analyses to modeling how retirement behavior changes as a function of expectations.

Furthermore, an additional distribution of a survey similar to survey module 479 in the next year will allow for measurement of outcomes of interest for the fifth of the population about to receive a new Statement and provide greater measurement of year-to-year variation in these outcomes, as well as changes in claiming behavior. Such a survey would also contain more directly comparable savings-measure outcomes, the refinement of which, even given the current array of ALP survey modules, would provide less noisy estimates of the Statement's impact on 
the vital and classic question of public policy: To what extent do public old age insurance programs crowd out private savings?

This analysis has found that individuals greatly value the information contained in the Statement as well as access to my Social Security accounts, and that they actively use this information in constructing their own expectations and, to some extent, plan their engagement in the labor market. With the ongoing ALP, analyses may be able to uncover which types of respondents are most sensitive to ongoing information outreach. 


\section{References}

Armour, Philip, forthcoming. “The Role of Information in Disability Insurance Application: An Analysis of the Social Security Statement Phase-In,” American Economic Journal: Economic Policy

Armour, Philip and Michael Lovenheim, 2017. "The Effect of Social Security Information on the Labor Supply of Older Americans,” Unpublished manuscript.

Biggs, Andrew G, 2010. “Improving the Social Security Statement.” Financial Literacy Center Working Paper.

Friedberg, Leora, 2000. "The Labor Supply Effects of the Social Security Earnings Test." The Review of Economics and Statistics

Greenwald, Matthew, Arie Kapteyn, Olivia Mitchell, and Lisa Schneider, 2010. "What Do People Know about Social Security?” Financial Literacy Center Working Paper

Liebman, Jeffrey B., and Erzo FP Luttmer, 2015. "Would people behave differently if they better understood Social Security? Evidence from a field experiment.” American Economic Journal: Economic Policy

Liebman, Jeffrey B., Erzo FP Luttmer, and David G. Seif, 2009. "Labor Supply Responses to Marginal Social Security Benefits: Evidence from Discontinuities." Journal of Public Economics

Mastrobuoni, Giovanni, 2011. “The Role of Information for Retirement Behavior: Evidence Based on the Stepwise Introduction of the Social Security Statement,” Journal of Public Economics.

Smith, Barbara A., and Kenneth A. Couch, 2014. "The Social Security Statement: Background, Implementation, and Recent Developments," Social Security Bulletin

Smith, Barbara A., and Kenneth A. Couch, 2016. “The Social Security Statement and Timing of Retirement Benefit Receipt,” Unpublished manuscript. 
Figure 1: Distribution of Those Not Remembering a Recent Statement, by Age, Weighted

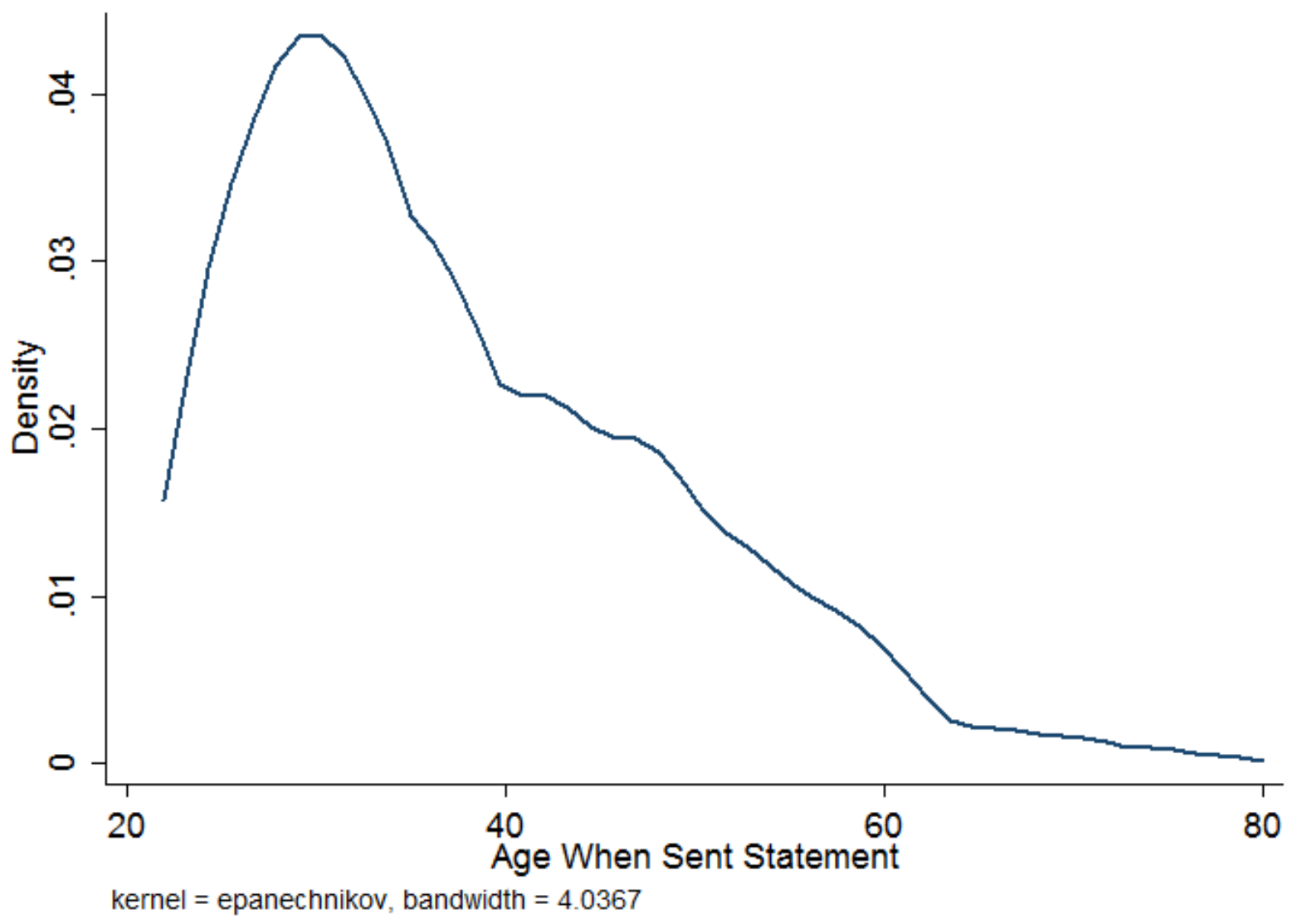

Note: Weighted calculation of individuals who would have been sent a Social Security Statement since 2014 due to not having opened a my Social Security account by the year of sending and their birthyear, and who do not recall receiving a Statement in the past five years. 
Table 1: Demographic Characteristics by Social Security Information Exposure

\begin{tabular}{lllll} 
& Overall & $\begin{array}{l}\text { Has a my } \\
\text { Social Security } \\
\text { account }\end{array}$ & $\begin{array}{l}\text { 2017 - Not Sent } \\
\text { a Statement } \\
\text { Since 2014 }\end{array}$ & $\begin{array}{l}\text { 2017 - Sent a } \\
\text { Statement since } \\
\mathbf{2 0 1 4}\end{array}$ \\
\hline \multirow{2}{*}{ Age } & 51.29 & 54.82 & 51.67 & 51.01 \\
Female & $(15.04)$ & $(12.14)$ & $(14.87)$ & $(15.15)$ \\
White & 0.52 & 0.41 & 0.57 & 0.49 \\
Black & $(0.50)$ & $(0.49)$ & $(0.50)$ & $(0.50)$ \\
Other & 0.67 & 0.61 & 0.54 & 0.75 \\
High School or Less & $(0.47)$ & $(0.49)$ & $(0.50)$ & $(0.43)$ \\
& 0.11 & 0.12 & 0.12 & 0.11 \\
Some College & $(0.32)$ & $(0.32)$ & $(0.33)$ & $(0.31)$ \\
& $(0.22$ & 0.27 & 0.34 & 0.14 \\
Bachelor Degree & $(0.42)$ & $(0.44)$ & $(0.47)$ & $(0.35)$ \\
& 0.41 & 0.34 & 0.46 & 0.38 \\
Graduate Degree & $(0.44)$ & $(0.47)$ & $(0.50)$ & $(0.49)$ \\
& 0.16 & 0.27 & 0.23 & 0.28 \\
Own Income & $(0.37)$ & $(0.44)$ & $(0.42)$ & $(0.45)$ \\
Observations & 0.16 & 0.20 & 0.15 & 0.17 \\
& $(0.37)$ & $(0.40)$ & $(0.36)$ & $(0.38)$ \\
& $80,606.99$ & 0.20 & 0.16 & 0.16 \\
& $(285,797.10)$ & $(53,062.07)$ & $(214,939.80)$ & $(326,209.90)$ \\
& 1,260 & 435 & 493 & 767 \\
\hline
\end{tabular}

Note: Weighted averages of demographic and income measures in the 2017 ALP survey discussed in this paper. Standard deviations in parentheses. 
Table 2: Knowledge of Social Security Benefits in 2010

\begin{tabular}{|c|c|c|c|c|}
\hline & Overall & $\begin{array}{l}2017 \text { - Has a my } \\
\text { Social Security } \\
\text { Account }\end{array}$ & $\begin{array}{l}2017 \text { - Not Sent } \\
\text { a Statement } \\
\text { Since } 2014\end{array}$ & $\begin{array}{l}2017 \text { - Sent a } \\
\text { Statement since } \\
2014\end{array}$ \\
\hline \multicolumn{5}{|l|}{2010 Correct Answer With Regard to: } \\
\hline SS Benefits Based on Highest 35 Year Average & $\begin{array}{l}0.20 \\
(0.40)\end{array}$ & $\begin{array}{l}0.26 \\
(0.44)\end{array}$ & $\begin{array}{l}0.17 \\
(0.38)\end{array}$ & $\begin{array}{l}0.23 \\
(0.42)\end{array}$ \\
\hline SS Benefits Can Be Taxed & $\begin{array}{l}0.60 \\
(0.49)\end{array}$ & $\begin{array}{l}0.69 \\
(0.46)\end{array}$ & $\begin{array}{l}0.61 \\
(0.49)\end{array}$ & $\begin{array}{l}0.59 \\
(0.49)\end{array}$ \\
\hline SS Benefits Indexed to Inflation & $\begin{array}{l}0.48 \\
(0.50)\end{array}$ & $\begin{array}{l}0.50 \\
(0.50)\end{array}$ & $\begin{array}{l}0.50 \\
(0.50)\end{array}$ & $\begin{array}{l}0.48 \\
(0.50)\end{array}$ \\
\hline Claiming Age Affects SS Benefits & $\begin{array}{l}0.61 \\
(0.49)\end{array}$ & $\begin{array}{l}0.71 \\
(0.45)\end{array}$ & $\begin{array}{l}0.58 \\
(0.49)\end{array}$ & $\begin{array}{l}0.63 \\
(0.48)\end{array}$ \\
\hline Spouses Can Receive Benefits & $\begin{array}{l}0.60 \\
(0.49)\end{array}$ & $\begin{array}{l}0.71 \\
(0.46)\end{array}$ & $\begin{array}{l}0.60 \\
(0.49)\end{array}$ & $\begin{array}{l}0.60 \\
(0.49)\end{array}$ \\
\hline $\begin{array}{l}\text { Can Collect at Different Time Age than } \\
\text { Retirement }\end{array}$ & $\begin{array}{l}0.60 \\
(0.49)\end{array}$ & $\begin{array}{l}0.70 \\
(0.46)\end{array}$ & $\begin{array}{l}0.62 \\
(0.49)\end{array}$ & $\begin{array}{l}0.59 \\
(0.49)\end{array}$ \\
\hline Can Collect SS Benefits if Disabled & $\begin{array}{l}0.64 \\
(0.48)\end{array}$ & $\begin{array}{l}0.75 \\
(0.43)\end{array}$ & $\begin{array}{l}0.63 \\
(0.48)\end{array}$ & $\begin{array}{l}0.64 \\
(0.48)\end{array}$ \\
\hline Greenwald et al. SS Knowledge Score (0-7) & $\begin{array}{l}3.74 \\
(2.45)\end{array}$ & $\begin{array}{l}4.31 \\
(2.31)\end{array}$ & $\begin{array}{l}3.71 \\
(2.45)\end{array}$ & $\begin{array}{l}3.76 \\
(2.46)\end{array}$ \\
\hline Observations & 1,260 & 435 & 492 & 767 \\
\hline
\end{tabular}

Note: Weighted averages of SS knowledge from the 2010 ALP Module "What Do People Know." Standard deviations in parentheses 
Table 3: Expectations of Social Security Benefits

\begin{tabular}{|c|c|c|c|c|c|}
\hline & $\begin{array}{l}2013 / 2014 \\
\text { Measures }\end{array}$ & $\begin{array}{l}2017 \\
\text { Measures }\end{array}$ & $\begin{array}{l}2017 \text { - Has a } \\
\text { my Social } \\
\text { Security } \\
\text { account }\end{array}$ & $\begin{array}{l}2017 \text { - Not } \\
\text { Sent a } \\
\text { Statement } \\
\text { Since } 2014 \\
\end{array}$ & $\begin{array}{l}2017 \text { - Sent a } \\
\text { Statement } \\
\text { since } 2014\end{array}$ \\
\hline Currently Receiving SS Income & $\begin{array}{l}0.21 \\
(0.41)\end{array}$ & $\begin{array}{l}0.29 \\
(0.46)\end{array}$ & $\begin{array}{l}0.39 \\
(0.49)\end{array}$ & $\begin{array}{l}0.28 \\
(0.45)\end{array}$ & $\begin{array}{l}0.30 \\
(0.46)\end{array}$ \\
\hline
\end{tabular}

If Not Currently Receiving SS Income

\begin{tabular}{|c|c|c|c|c|c|}
\hline Expects to Receive SS Income in the Future & $\begin{array}{l}0.55 \\
(0.50)\end{array}$ & $\begin{array}{l}0.53 \\
(0.50)\end{array}$ & $\begin{array}{l}0.52 \\
(0.50)\end{array}$ & $\begin{array}{l}0.49 \\
(0.50)\end{array}$ & $\begin{array}{l}0.56 \\
(0.50)\end{array}$ \\
\hline Age Expects to First Collect SS Income & $\begin{array}{l}65.62 \\
(4.43)\end{array}$ & $\begin{array}{l}64.69 \\
(7.90)\end{array}$ & $\begin{array}{l}65.06 \\
(5.91)\end{array}$ & $\begin{array}{l}65.41 \\
(5.31)\end{array}$ & $\begin{array}{l}64.22 \\
(9.18)\end{array}$ \\
\hline Expected Amount of Monthly SS Income & $\begin{array}{l}1,492.23 \\
(1,119.74)\end{array}$ & $\begin{array}{l}1,533.45 \\
(870.84)\end{array}$ & $\begin{array}{l}1,684.61 \\
(764.47)\end{array}$ & $\begin{array}{l}1,569.16 \\
(821.20)\end{array}$ & $\begin{array}{l}1,509.95 \\
(902.35)\end{array}$ \\
\hline \multicolumn{6}{|l|}{ In Next 10 Years, \% Likelihood Congress will Make } \\
\hline SS Less Generous Overall in Next 10 Years & $\begin{array}{l}62.55 \\
(31.56)\end{array}$ & $\begin{array}{l}58.87 \\
(28.35)\end{array}$ & $\begin{array}{l}54.93 \\
(28.65)\end{array}$ & $\begin{array}{l}61.29 \\
(28.22)\end{array}$ & $\begin{array}{l}57.10 \\
(28.33)\end{array}$ \\
\hline $\begin{array}{l}\text { Own SS Entitlement Less Generous in Next } 10 \\
\text { Years }\end{array}$ & $\begin{array}{l}59.65 \\
(31.55)\end{array}$ & $\begin{array}{l}56.85 \\
(31.16)\end{array}$ & $\begin{array}{l}50.14 \\
(29.50)\end{array}$ & $\begin{array}{l}55.94 \\
(32.12)\end{array}$ & $\begin{array}{l}57.51 \\
(30.45)\end{array}$ \\
\hline Observations & 1,260 & 1,260 & 435 & 493 & 767 \\
\hline
\end{tabular}

Note: Weighted averages of SS benefit receipt and SS expectations in the 2013/2014 ALP HRS survey modules and 2017 ALP survey discussed in this paper. Standard deviations in parentheses. 
Table 4: Expectations of Type of Future Social Security Benefit

\begin{tabular}{|c|c|c|c|c|}
\hline & $\begin{array}{l}2017 \\
\text { Measures }\end{array}$ & $\begin{array}{l}2017 \text { - Has a } \\
\text { my Social } \\
\text { Security } \\
\text { account }\end{array}$ & $\begin{array}{l}2017 \text { - Not } \\
\text { Sent a } \\
\text { Statement } \\
\text { Since } 2014 \\
\end{array}$ & $\begin{array}{l}2017 \text { - Sent a } \\
\text { Statement } \\
\text { since } 2014\end{array}$ \\
\hline \multicolumn{5}{|c|}{$\begin{array}{l}\text { Among Those Expecting SS } \\
\text { Benefits, Expected Benefit Type }\end{array}$} \\
\hline Retirement & $\begin{array}{l}0.91 \\
(0.28)\end{array}$ & $\begin{array}{l}0.96 \\
(0.19)\end{array}$ & $\begin{array}{l}0.94 \\
(0.24)\end{array}$ & $\begin{array}{l}0.90 \\
(0.31)\end{array}$ \\
\hline Disability & $\begin{array}{l}0.09 \\
(0.29)\end{array}$ & $\begin{array}{l}0.16 \\
(0.37)\end{array}$ & $\begin{array}{l}0.11 \\
(0.31)\end{array}$ & $\begin{array}{l}0.08 \\
(0.28)\end{array}$ \\
\hline Spousal & $\begin{array}{l}0.09 \\
(0.29)\end{array}$ & $\begin{array}{l}0.10 \\
(0.30)\end{array}$ & $\begin{array}{l}0.08 \\
(0.27)\end{array}$ & $\begin{array}{l}0.10 \\
(0.30)\end{array}$ \\
\hline Survivors & $\begin{array}{l}0.02 \\
(0.15)\end{array}$ & $\begin{array}{l}0.01 \\
(0.11)\end{array}$ & $\begin{array}{l}0.02 \\
(0.13)\end{array}$ & $\begin{array}{l}0.02 \\
(0.15)\end{array}$ \\
\hline Dependent & $\begin{array}{l}0.00 \\
(0.06)\end{array}$ & $\begin{array}{l}0.00 \\
0.00\end{array}$ & $\begin{array}{l}0.00 \\
(0.07)\end{array}$ & $\begin{array}{l}0.00 \\
(0.06)\end{array}$ \\
\hline Don't Know & $\begin{array}{l}0.04 \\
(0.20)\end{array}$ & $\begin{array}{l}0.02 \\
(0.13)\end{array}$ & $\begin{array}{l}0.04 \\
(0.20)\end{array}$ & $\begin{array}{l}0.04 \\
(0.19)\end{array}$ \\
\hline Observations & 626 & 222 & 238 & 388 \\
\hline
\end{tabular}

Note: Weighted averages of which SS benefits individuals expect among those expecting SS benefits in the 2017 ALP survey discussed in this paper. Standard deviations in parentheses. 
Table 5: Savings Behavior among American Life Panel Respondents

\begin{tabular}{|c|c|c|c|c|c|}
\hline & $\begin{array}{l}2013 / 2014 \\
\text { Measures }\end{array}$ & $\begin{array}{l}2017 \\
\text { Measures }\end{array}$ & $\begin{array}{l}2017 \text { - Has a } \\
\text { my Social } \\
\text { Security } \\
\text { account }\end{array}$ & $\begin{array}{l}2017 \text { - Not } \\
\text { Sent a } \\
\text { Statement } \\
\text { Since } 2014 \\
\end{array}$ & $\begin{array}{l}2017 \text { - Sent a } \\
\text { Statement } \\
\text { since } 2014\end{array}$ \\
\hline IRA in Household & $\begin{array}{l}0.37 \\
(0.48)\end{array}$ & $\begin{array}{l}0.42 \\
(0.49)\end{array}$ & $\begin{array}{l}0.45 \\
(0.50)\end{array}$ & $\begin{array}{l}0.41 \\
(0.49)\end{array}$ & $\begin{array}{l}0.42 \\
(0.49)\end{array}$ \\
\hline Contributed to IRA in Past Year & $\begin{array}{l}0.16 \\
(0.36)\end{array}$ & $\begin{array}{l}0.16 \\
(0.37)\end{array}$ & $\begin{array}{l}0.17 \\
(0.38)\end{array}$ & $\begin{array}{l}0.14 \\
(0.35)\end{array}$ & $\begin{array}{l}0.17 \\
(0.38)\end{array}$ \\
\hline Amount of IRA Contribution & $\begin{array}{l}15,243.74 \\
(16,579.42)\end{array}$ & $\begin{array}{l}8,131.27 \\
(14,140.28)\end{array}$ & $\begin{array}{l}10,817.39 \\
(15,438.03)\end{array}$ & $\begin{array}{l}7,689.49 \\
(13,685.69)\end{array}$ & $\begin{array}{l}8,389.36 \\
(14,440.73)\end{array}$ \\
\hline Pension in Household & & $\begin{array}{l}0.39 \\
(0.49)\end{array}$ & $\begin{array}{l}0.46 \\
(0.50)\end{array}$ & $\begin{array}{l}0.38 \\
(0.49)\end{array}$ & $\begin{array}{l}0.39 \\
(0.49)\end{array}$ \\
\hline Contributed to Pension in Past Year & & $\begin{array}{l}0.27 \\
(0.44)\end{array}$ & $\begin{array}{l}0.35 \\
(0.48)\end{array}$ & $\begin{array}{l}0.27 \\
(0.45)\end{array}$ & $\begin{array}{l}0.26 \\
(0.44)\end{array}$ \\
\hline Amount of Pension Contribution & & $\begin{array}{l}8,008.43 \\
(19,127.04)\end{array}$ & $\begin{array}{l}6,911.34 \\
(10,546.10)\end{array}$ & $\begin{array}{l}7,678.24 \\
(23,703.77)\end{array}$ & $\begin{array}{l}8,252.06 \\
(14,948.97)\end{array}$ \\
\hline Any Other Long-Term Savings & & $\begin{array}{l}0.21 \\
(0.40)\end{array}$ & $\begin{array}{l}0.25 \\
(0.44)\end{array}$ & $\begin{array}{l}0.19 \\
(0.39)\end{array}$ & $\begin{array}{l}0.22 \\
(0.41)\end{array}$ \\
\hline Contributed to Other Long-Term Savings & & $\begin{array}{l}0.06 \\
(0.24)\end{array}$ & $\begin{array}{l}0.08 \\
(0.27)\end{array}$ & $\begin{array}{l}0.04 \\
(0.20)\end{array}$ & $\begin{array}{l}0.08 \\
(0.26)\end{array}$ \\
\hline $\begin{array}{l}\text { Amount of Contribution to Long-Term } \\
\text { Savings }\end{array}$ & & $\begin{array}{l}135.29 \\
(3,065.70)\end{array}$ & $\begin{array}{l}54.93 \\
(28.65)\end{array}$ & $\begin{array}{l}62.77 \\
(74.41)\end{array}$ & $\begin{array}{l}188.47 \\
(4,036.12)\end{array}$ \\
\hline Observations & 1,260 & 1,260 & 435 & 493 & 767 \\
\hline
\end{tabular}

Note: Weighted averages of savings measures in either 2013/2014 ALP survey asking HRS modules J-M or the 2017 ALP survey discussed in this paper. Standard deviations in parentheses. 
Table 6: Labor Supply among American Life Panel Respondents

\begin{tabular}{|c|c|c|c|c|c|}
\hline & $\begin{array}{l}\text { 2013/2014 } \\
\text { Measures }\end{array}$ & $\begin{array}{l}2017 \\
\text { Measures }\end{array}$ & $\begin{array}{l}2017 \text { - Has a } \\
\text { my Social } \\
\text { Security } \\
\text { account }\end{array}$ & $\begin{array}{l}2017 \text { - Not } \\
\text { Sent a } \\
\text { Statement } \\
\text { Since } 2014\end{array}$ & $\begin{array}{l}2017 \text { - Sent a } \\
\text { Statement } \\
\text { since } 2014\end{array}$ \\
\hline Working & $\begin{array}{l}0.65 \\
(0.48)\end{array}$ & $\begin{array}{l}0.60 \\
(0.49)\end{array}$ & $\begin{array}{l}0.55 \\
(0.50)\end{array}$ & $\begin{array}{l}0.58 \\
(0.49)\end{array}$ & $\begin{array}{l}0.61 \\
(0.49)\end{array}$ \\
\hline
\end{tabular}

\begin{tabular}{llllll} 
Among Workers, Hours Worked/Week: & & & \\
\hline Working fewer than 10 Hours & 0.05 & 0.03 & 0.03 & 0.04 & 0.03 \\
& $(0.22)$ & $(0.18)$ & $(0.18)$ & $(0.20)$ & $(0.17)$ \\
Working 10-29 Hours & 0.09 & 0.10 & 0.13 & 0.10 & 0.09 \\
& $(0.28)$ & $(0.29)$ & $(0.34)$ & $(0.30)$ & $(0.29)$ \\
Working 30-39 Hours & 0.14 & 0.09 & 0.06 & 0.13 & 0.06 \\
& $(0.35)$ & $(0.29)$ & $(0.23)$ & $(0.34)$ & $(0.25)$ \\
Working Exactly 40 Hours & 0.39 & 0.42 & 0.37 & 0.39 & 0.43 \\
& $(0.49)$ & $(0.49)$ & $(0.48)$ & $(0.49)$ & $(0.50)$ \\
Working over 40 Hours & 0.33 & 0.36 & 0.41 & 0.34 & 0.38 \\
& $(0.47)$ & $(0.48)$ & $(0.49)$ & $(0.47)$ & $(0.49)$ \\
Total Annual Hours Worked & $1,886.31$ & $1,916.83$ & $1,876.14$ & $1,865.22$ & $1,952.23$ \\
& $(719.35)$ & $(709.05)$ & $(744.08)$ & $(673.11)$ & $(731.43)$ \\
Observations & & & & & \\
\hline
\end{tabular}

Note: Weighted averages of working at all or hours worked in either 2013/2014 ALP survey asking HRS modules J-M or the 2017 ALP survey discussed in this paper. Standard deviations in parentheses. 
Table 7: Recall of Social Security Statement and my Social Security Accounts

\begin{tabular}{lll} 
& $\begin{array}{l}\text { Weighted } \\
\text { Average }\end{array}$ & $\mathbf{N}$ \\
\hline Currently Receiving SS Income & 0.29 & 1260
\end{tabular}

Among Those Not Receiving SS Income

\begin{tabular}{lll}
\hline Remember Ever Receiving Statement & 0.71 & 741 \\
Sent Statement/Reminder Since 2014 & 0.58 & 741 \\
Has a my Social Security Account & 0.24 & 741 \\
Not Sent a Statement Due to my Social Security Account & 0.14 & 459 \\
Don't Remember Recent Statement & 0.32 & 372 \\
\hline
\end{tabular}

Note: weighted average of those reporting any SS income and Statement receipt and my Social Security account status among those who did not. Individuals who sign up for a my Social Security account are sent annual reminder emails to check their account. If an individual has signed up for a my Social Security account, they are not sent a Statement. The last row is the fraction of those who would have been sent a Statement (i.e., reached a fifth birthday, such as 30, 35, or 40, and did not report signing up for a my Social Security account prior to the year a Statement would be sent), but did not report receiving a Statement in the past five years. 
Table 8: Usefulness of Social Security Information

\begin{tabular}{lll} 
& & $\begin{array}{c}\text { my Social } \\
\text { Security } \\
\text { account }\end{array}$ \\
\hline $\begin{array}{l}\text { Found Useful For Retirement Planning or SS } \\
\text { Claiming }\end{array}$ & 0.61 & 0.74 \\
& & \\
Among Those Who Found it Useful & & 0.60 \\
Planning When to Retire & 0.67 & 0.62 \\
$\begin{array}{l}\text { Planning When to Claim SS Retirement } \\
\text { Deciding Whether to Claim SS Disability }\end{array}$ & 0.64 & 0.17 \\
Deciding Whether to Claim Other SS Benefits & 0.12 & 0.14 \\
\hline
\end{tabular}

Note: weighted averages among those reporting ever receiving a Social Security Statement or report having signed up for a my Social Security account 
Table 9: Linear Regression Coefficients of Statement Impact and Select Covariates on Social Security Expectations of Own Benefits

\begin{tabular}{|c|c|c|c|c|c|c|c|c|}
\hline & $\begin{array}{l}\text { (1) } \\
\text { Expect } \\
\text { Any SS } \\
\text { Benefit } \\
\end{array}$ & $\begin{array}{l}\text { (2) } \\
\text { Expect to } \mathrm{F}\end{array}$ & ive SS Disabi & (4) & $\begin{array}{l}\text { (5) } \\
\text { Expecting }\end{array}$ & Claim Age & $\begin{array}{l}\text { Expected Monthly } \\
\text { Benefit }\end{array}$ & $\begin{array}{l}\text { (8) } \\
\text { onthly }\end{array}$ \\
\hline Recent Statement & $\begin{array}{l}0.120 * * * \\
(0.0301)\end{array}$ & $\begin{array}{l}-0.0159 \\
(0.0225)\end{array}$ & $\begin{array}{l}0.128 * * \\
(0.0582)\end{array}$ & $\begin{array}{l}-0.0415 * \\
(0.0220)\end{array}$ & $\begin{array}{l}-0.261 \\
(0.555)\end{array}$ & $\begin{array}{l}0.306 \\
(0.257)\end{array}$ & $\begin{array}{l}-10.94 \\
(74.63)\end{array}$ & $\begin{array}{l}-86.75 \\
(85.42)\end{array}$ \\
\hline $\begin{array}{l}\text { 2013/2014 Claim Age } \\
\text { Expectation }\end{array}$ & & & & & & $\begin{array}{l}0.596 * * * \\
(0.0310)\end{array}$ & & \\
\hline $\begin{array}{l}\text { 2013/2014 Monthly Benefit } \\
\text { Expectation }\end{array}$ & & & & & & & & $\begin{array}{l}0.437 * * * \\
(0.0518)\end{array}$ \\
\hline $\begin{array}{l}\text { Had my Social Security } \\
\text { Account }\end{array}$ & $\begin{array}{l}0.0122 \\
(0.0375)\end{array}$ & $\begin{array}{l}0.110^{* * *} \\
(0.0270)\end{array}$ & $\begin{array}{l}0.00610 \\
(0.0755)\end{array}$ & $\begin{array}{l}0.156^{* * *} \\
(0.0245)\end{array}$ & $\begin{array}{l}-2.405^{* * *} \\
(0.652)\end{array}$ & $\begin{array}{l}0.239 \\
(0.288)\end{array}$ & $\begin{array}{l}56.19 \\
(87.88)\end{array}$ & $\begin{array}{l}-9.712 \\
(95.05)\end{array}$ \\
\hline Sample & $\begin{array}{l}\text { Non- } \\
\text { Recipients }\end{array}$ & $\begin{array}{l}\text { Non- } \\
\text { Recipients } \\
\text { matched to } \\
\text { 2013/2014 } \\
\text { Modules }\end{array}$ & $\begin{array}{l}\text { Non- } \\
\text { Recipients, } \\
\text { Previously } \\
\text { Did Not } \\
\text { Expect Any } \\
\text { SS Benefits }\end{array}$ & $\begin{array}{l}\text { Non- } \\
\text { Recipients, } \\
\text { Previously } \\
\text { Expected } \\
\text { Any SS } \\
\text { Benefits }\end{array}$ & $\begin{array}{l}\text { Non- } \\
\text { Recipients }\end{array}$ & $\begin{array}{l}\text { Non- } \\
\text { Recipients }\end{array}$ & $\begin{array}{l}\text { Non- } \\
\text { Recipients }\end{array}$ & $\begin{array}{l}\text { Non- } \\
\text { Recipients }\end{array}$ \\
\hline Observations & 719 & 625 & 126 & 497 & 624 & 497 & 618 & 492 \\
\hline R-squared & 0.257 & 0.279 & 0.585 & 0.327 & 0.419 & 0.518 & 0.139 & 0.294 \\
\hline
\end{tabular}

Standard errors in parentheses, clustered at age level. All regressions weighted and control for age, age squared, sex, race/ethnicity, prior knowledge, and education.

$* * * \mathrm{p}<0.01, * * \mathrm{p}<0.05,{ }^{*} \mathrm{p}<0.1$ 
Table 10: Linear Regression Coefficients of Statement Impact and Select Covariates on General Social Security Expectations

\begin{tabular}{|c|c|c|c|c|c|c|c|c|}
\hline & $\begin{array}{l}(1) \\
\text { Benefits } \\
\text { Rise if I } \\
\text { Earn } \\
25 \% \\
\text { More } \\
\end{array}$ & $\begin{array}{l}(2) \\
\text { Benefits } \\
\text { Fall if I } \\
\text { Earn } \\
25 \% \\
\text { Less } \\
\end{array}$ & $\begin{array}{l}\text { (3) } \\
\text { Benefits } \\
\text { Are } \\
\text { Higher } \\
\text { If I } \\
\text { Claim } \\
\text { Later }\end{array}$ & $\begin{array}{l}(4) \\
\text { Benefits } \\
\text { Are } \\
\text { Lower if } \\
\text { I Claim } \\
\text { Earlier }\end{array}$ & $\begin{array}{l}\text { \% Chance } \\
\text { Generous }\end{array}$ & S Less & $\begin{array}{l}\text { \% Chance } \\
\text { Generous }\end{array}$ & My SS Less \\
\hline Recent Statement & $\begin{array}{l}-0.0827 \\
(0.0646)\end{array}$ & $\begin{array}{l}-0.120 * \\
(0.0643)\end{array}$ & $\begin{array}{l}0.0119 \\
(0.0430)\end{array}$ & $\begin{array}{l}-0.0120 \\
(0.0433)\end{array}$ & $\begin{array}{l}-7.273^{* * *} \\
(2.112)\end{array}$ & $\begin{array}{l}-5.267 * * \\
(2.039)\end{array}$ & $\begin{array}{l}-2.267 \\
(2.135)\end{array}$ & $\begin{array}{l}4.796^{*} \\
(2.544)\end{array}$ \\
\hline 2013/2014 \% Chance SS Less Generous & & & & & & $\begin{array}{l}0.308 * * * \\
(0.0330)\end{array}$ & & \\
\hline 2013/2014 \% Chance My SS Less Generous & & & & & & & & $\begin{array}{l}0.338 * * * \\
(0.0442)\end{array}$ \\
\hline Had my Social Security Account & $\begin{array}{l}-0.0181 \\
(0.0704)\end{array}$ & $\begin{array}{l}0.00913 \\
(0.0701)\end{array}$ & $\begin{array}{l}0.0237 \\
(0.0508)\end{array}$ & $\begin{array}{l}0.0407 \\
(0.0511)\end{array}$ & $\begin{array}{l}-4.029 \\
(2.593)\end{array}$ & $\begin{array}{l}1.132 \\
(2.562)\end{array}$ & $\begin{array}{l}-10.81^{* * *} \\
(2.621)\end{array}$ & $\begin{array}{l}-0.856 \\
(2.895)\end{array}$ \\
\hline Observations & 236 & 236 & 573 & 573 & 682 & 655 & 682 & 466 \\
\hline R-squared & 0.195 & 0.254 & 0.149 & 0.079 & 0.153 & 0.251 & 0.242 & 0.311 \\
\hline
\end{tabular}

Standard errors in parentheses, clustered at age level. All regressions weighted and control for age, age squared, sex, race/ethnicity, prior knowledge, and education. \% Chance measures based on 0-100 percent chance that the respondent considers Congress will make Social Security as a system less generous or lowering his/her own SS benefits in the next 10 years.

$* * * \mathrm{p}<0.01, * * \mathrm{p}<0.05, * \mathrm{p}<0.1$ 
Table 11: Linear Regression Coefficients of Statement Impact and Select Covariates on Savings Behavior

\begin{tabular}{|c|c|c|c|c|c|}
\hline & \multicolumn{3}{|l|}{ IRA } & \multicolumn{2}{|l|}{ Pension } \\
\hline & (1) & (2) & (3) & (4) & (5) \\
\hline & $\begin{array}{l}\text { Any } \\
\text { Contribution }\end{array}$ & $\begin{array}{l}\text { Contribution } \\
\text { Amount }\end{array}$ & $\begin{array}{l}\text { Contribution } \\
\text { Amount }\end{array}$ & $\begin{array}{l}\text { Any } \\
\text { Contribution }\end{array}$ & $\begin{array}{l}\text { Contribution } \\
\text { Amount }\end{array}$ \\
\hline Recent Statement & $\begin{array}{l}-0.0217 \\
(0.0322)\end{array}$ & $\begin{array}{l}1,702 \\
(2,299)\end{array}$ & $\begin{array}{l}584.1 \\
(2,371)\end{array}$ & $\begin{array}{l}-0.00450 \\
(0.0371)\end{array}$ & $\begin{array}{l}-2,471 \\
(2,556)\end{array}$ \\
\hline Under $40 \mathrm{X}$ Statement & & & & & \\
\hline 40-49 X Statement & & & & & \\
\hline 50-59 X Statement & & & & & \\
\hline 60 and Over X Statement & & & & & \\
\hline IRA Contribution Amount in 2013/2014 & & & $\begin{array}{l}0.139 * \\
(0.0788)\end{array}$ & & \\
\hline Had my Social Security Account & $\begin{array}{l}0.00637 \\
(0.0402)\end{array}$ & $\begin{array}{l}3,892 \\
(2,776)\end{array}$ & $\begin{array}{l}3,859 \\
(2,759)\end{array}$ & $\begin{array}{l}0.108 * * \\
(0.0462)\end{array}$ & $\begin{array}{l}-3,608 \\
(2,958)\end{array}$ \\
\hline Observations & 719 & 191 & 191 & 719 & 299 \\
\hline R-squared & 0.080 & 0.094 & 0.110 & 0.161 & 0.091 \\
\hline
\end{tabular}

Standard errors in parentheses, clustered at age level. All regressions weighted and control for age, age squared, sex, race/ethnicity, prior knowledge, and education.

$* * * \mathrm{p}<0.01, * * \mathrm{p}<0.05, * \mathrm{p}<0.1$ 
Table 11 (cont'd): Linear Regression Coefficients of Statement Impact and Select Covariates on Savings Behavior

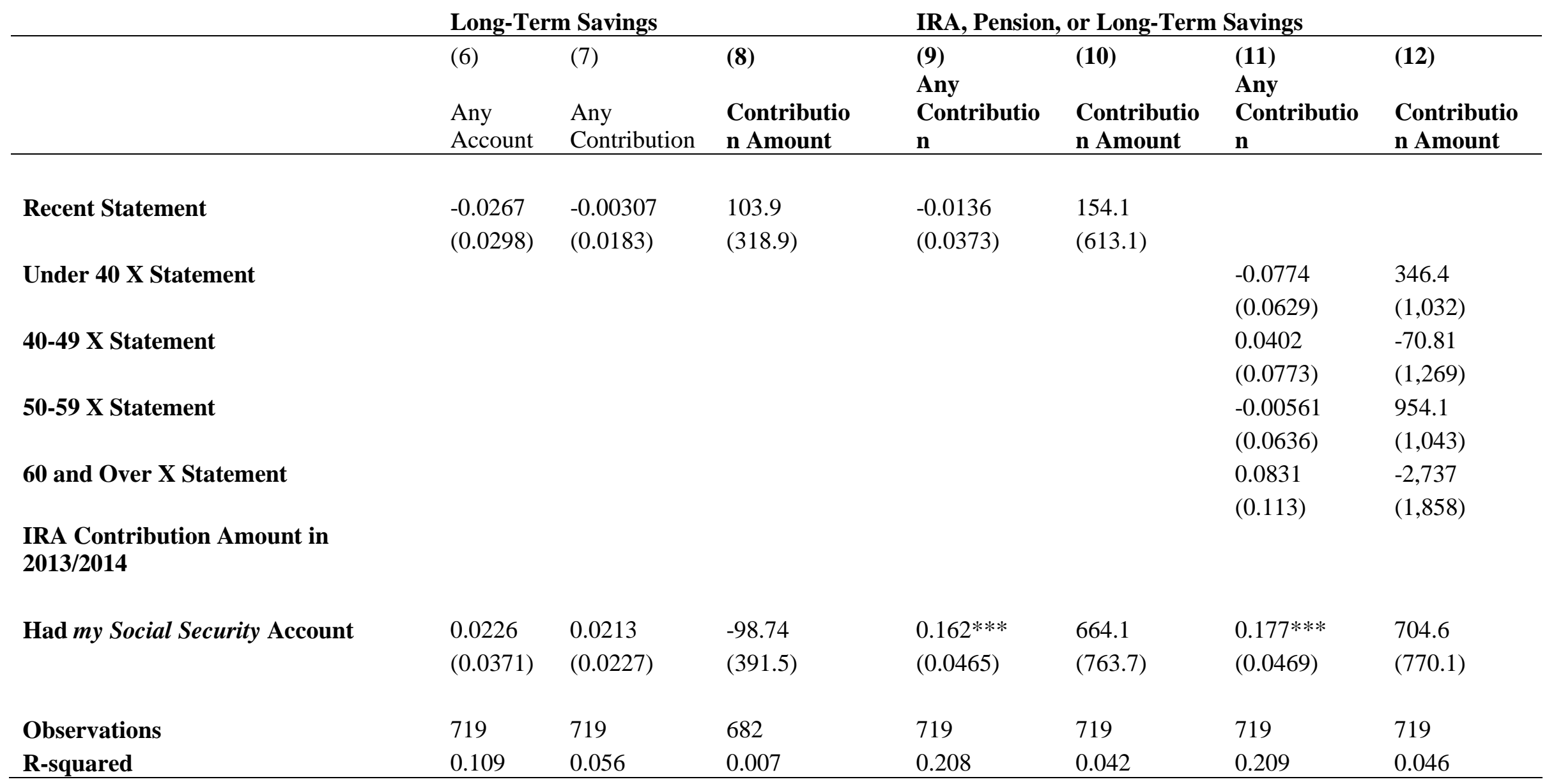

Standard errors in parentheses, clustered at age level. All regressions weighted and control for age, age squared, sex, race/ethnicity, prior knowledge, and education.

$* * * \mathrm{p}<0.01, * * \mathrm{p}<0.05, * \mathrm{p}<0.1$ 
Table 12: Linear Regression Coefficients of Statement Impact and Select Covariates on Work Behavior

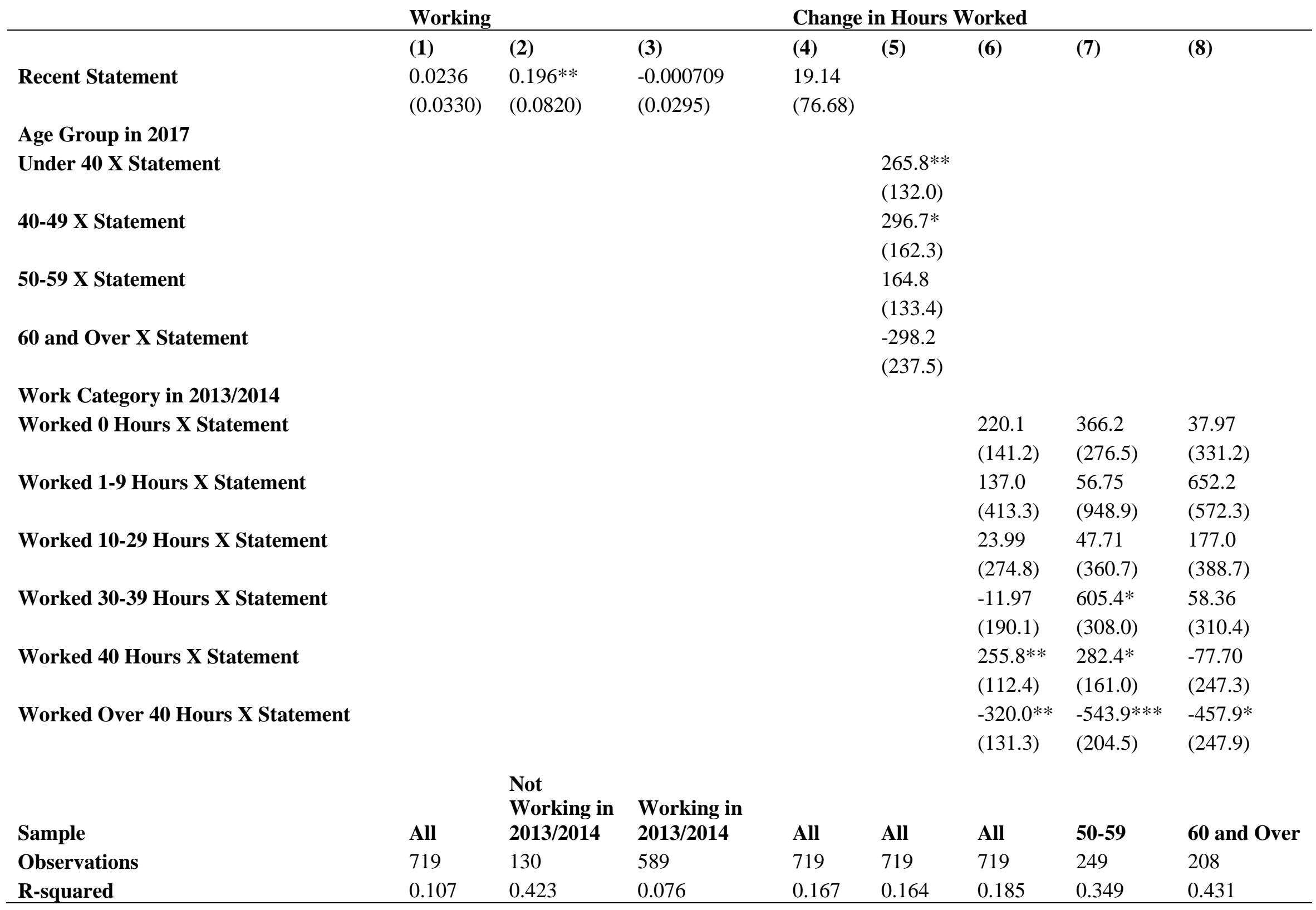

Standard errors in parentheses, clustered at age level. All regressions weighted and control for age group, prior hours worked, sex, race/ethnicity, education, whether respondent had a my Social Security account before recent Statement, and 2010 Social Security knowledge. ${ }^{* * *} \mathrm{p}<0.01,{ }^{* *} \mathrm{p}<0.05,{ }^{*} \mathrm{p}<0.1$ 